\title{
Pengaruh Aplikasi Alfatokoferol Terhadap Pertumbuhan dan Produksi Kedelai (Glycine Max (L). Merril) Di Tanah Salin
}

The Influence of Alpha Tocopherol Application To Growth And Production Of Soybean (Glycine Max (L) Merril) in Saline Soil

\author{
Heru Suganda*, Nini Rahmawati, Irsal \\ Program Studi Agroteknologi, Fakultas Pertanian USU, Medan 20155 \\ *Coressponding author :herusuganda12@gmail.com
}

\begin{abstract}
The production of soybean in Indonesia each year has decreased and can not fulfill need in country, one of the main causes of which is the narrowness of agricultural land. To increase soybean production in Indonesia can be achieved by expanding the planting area, namely by vitilizing the existing land potentially one of them with saline soil. This research was conducted in plastic house of Faculty of Agriculture, University of Sumatera Utara, Medan with height of place +25 meter above sea level from August 2017 until november 2017, using factorial randomized block design ie factor I: soybean genotypes Anjasmoro X Grobogan, and Grobogan X Grobogan,. Factor II: aplication of alpha tocopherol concentration with non alpha tocopherol, alpha tocopherol $250 \mathrm{ppm}$, alpha tocopherol 500 ppm, alpha tocopherol 750 ppm. Parameters abserved are of plant height, number of leaves, productive branch, flowering age, stem diameter, number of pods containing, harvest age, weight of 100 seeds of cultivation. The result of this research showed that use soybean progeny have a real impact to the parameters of plant height, number of leaves, productve branch, flowering ege, stem diameter, number of pods contaid, harvest age, weight of 100 seed of cultivation.
\end{abstract}

Keywords :alpha tocophrol, saline soil, salinity stress

\begin{abstract}
ABSTRAK
Produksi kedelai di indonesia setiap tahun mengalami penurunan dan tidak dapat memenuhi kebutuhan dalam negri, salah satu penyebab utamanya yaitu semangkin sempitnya lahan pertanian. Untuk meningkatkan produksi kedelai di Indonesia dapat ditempuh dengan cara perluasan areal tanam, yaitu dengan memanfaatkan tanah yang kurang berpotensi salah satunya adalah tanah salin. Penelitan ini dilaksanakan di rumah plastik Fakultas Pertanian Universitas Sumatera Utara, Medan dengan ketinggian tempat \pm 25 meter di atas permukaan laut dari bulan Agustus 2017 sampai november 2017, menggunakan rancangan acak kelompok faktorial yaitu faktor I: genotip kedelai Anjasmoro X Grobogan, dan Grobogan X Grobogan, faktor II: pemberian konsentrasi alfa tokoferol dengan taraf tanpa alfa tokoferol, alfa tokoferol $250 \mathrm{ppm}$, alfa tokoferol $500 \mathrm{ppm}$, alfa tokoferol $750 \mathrm{ppm}$. berpengaruh nyata terhadap parameter tinggi tanaman, jumlah daun, cabang produktif, umur berbunga, diameter batang, jumlah polong berisi, umur panen, bobot 100 biji pertanaman
\end{abstract}

Kata kunci :alfa tokoferol, cekaman salinitas, tanah salin

\section{PENDAHULUAN}

Kedelai (Glycine $\max$ L. Merril) merupakan salah satu komoditas pangan penting, baik untuk konsumsi langsung maupun sebagai bahan baku industri .Kebutuhan kedelai di Indonesia setiap tahun selalu meningkat seiring dengan 
pertumbuhan penduduk. Oleh karena itu diperlukan suplai kedelai tambahan yang harus diimpor karena produksi dalam negeri belum dapat mencukupi keadaan tersebut. Lahan budidaya kedelai pundiperluas dan produktivitasnya ditingkatkan (Triyani et al. 2013)

Kedelai juga merupakan salah satu sumber protein nabati dengan kandungan $39 \%$, 2\% dari seluruh rakyat Indonesia memperoleh sumber protein dari kedelai. Dilihat dari segi pangan dan gizi, kedelai merupakan sumber protein yang paling murah di dunia. Namun, sampai saat ini produksi kedelai di Indonesia belum bisa untuk memenuhi kebutuhan masyarakat Indonesia dan masih ketergantungan dengan impor kedelai dari luar negeri (Ramadhani, 2009).

Menurut BPS (2014) Produksi kedelai beberapa tahun terakhir mengalami fluktuasi, dimana pada tahun 2010 produksi kedelai sebesar 907.030 ton, namun pada tahun 2011 produksi kedelai turun menjadi 851.290 ton, pada tahun 2012 penurunan produksi kembali terjadi menjadi 843.150 ton dan tahun 2013 produksi kedelai semakin menurun menjadi 780.160 ton yang tidak memenuhi kebutuhan dalam negeri, dimana produksi kedelai dalam negeri hanya dapat memenuhi $35 \%$ dari kebutuhan total. Penurunan produksi kedelai diperkirakan terjadi karena turunnya luas panen seluas 13,49 ribu hektar dan produktivitas sebesar 0,28 kuintal/hektar.

Peningkatan produksi kedelai di Indonesia dapat ditempuh dengan cara perluasan areal tanam. Tantangannya adalah bagaimana mencapai areal tanam tersebut sementara lahan yang tersedia terbatas dan digunakan untuk berbagai tanaman palawija lainnya yang lebih kompetitif. Di sisi lain masih banyak tanah di Indonesia belum dimanfaatkan akibat keterbatasan teknik budidaya, salah satunya adalah tanah salin. Tanah salin adalah salah satu lahan yang belum dimanfaatkan secara luas untuk kegiatan budidaya tanaman yang disebabkan adanya

efek toksik dan peningkatan tekanan osmotik akar yang mengakibatkan terganggunya pertumbuhan tanaman (Ardiansyah, 2013).

Upaya yang dapat dilakukan dengan menggunakan antioksidan yang bertujuan untuk meningkatkan toleransi tanaman terhadap cekaman oksidatif yaitu alfatokoferol. Farouk (2011) menyatakan bahwa aplikasi $\alpha$-tokoferol dapat menurunkan akumulasi hydrogen peroksida dan meningkatkan aktivitas enzim wheat leaf di tanahsalin.

Penanaman galur kedelai yang toleran di lahan salin, merupakan salah satu alternatif dalam pengembangan dan peningkatan budidaya dan pertanaman kedelai. Untuk keperluan tersebut perlu dilakukan penelitian tentang respon morfologi yang dapat digunakan sebagai penanda untuk tanaman yang toleran terhadap salinitas dengan konsentrasi $\mathrm{NaCl}$ tinggi

Pada penelitian ini digunakan benih kedelai F5 tanahsalin yang merupakan hasil keturunan keempat dari silang balik (backcross) varietas Grobogan dan Anjasmoro yang telah diuji ketahanan salinnya di media tanam salin hingga keturunan ke-4 dan benih kedelai F5 tanah salin yang merupakan hasil keturunan keempat dari varietas Grobogan dan Grobogan yang telah diuji ketahanan salinnya di media tanam salin hingga keturunan ke-4. Akan tetapi pertumbuhan dan produksinya masih belum optimal baikdarisegi kualitas maupun kuantitasnya.

\section{BAHAN DAN METODE}

Penelitian ini dilaksanakan di
rumah plastik Fakultas Pertanian
Universitas Sumatera Utara, dengan
tingkat salinitas $6-7$ ds/m pada ketinggian
tempat $\pm 32 \mathrm{mdpl}$, penelitian dilakukan
pada bulan April 2017 sampai dengan
selesai.
Bahan yang digunakan ialah benih
kedelai F5 tahan terhadap salinitas 4-5
ds/m hasil dari persilangan antara varietas


Grobogan dan Anjasmoro $(\mathrm{G} \times \mathrm{A})$, benih kedelai F5 tahan terhadap salinitas 4-5 hasil dari persilangan antara varietas Grobogan dan Grobogan $(G \times G)$, antioksidan alfa tokoferol, tanah salin sebagai media tanam, plastik kaca sebagai atap rumah plastik, bambu sebagai kerangka rumah pelastik, kawat untuk mengikat antara tiap bambu, aquades sebagai pelarut alfatokoferol, plastik obat sebagai wada pupuk, polibag wadah untuk media tanam, pelastik sebagai pembalut polibag agar tanah tidak tercuci, air untuk menyiram tanaman, air laut untuk meningkatkan daya hantar listrik, pupuk Urea, TSP dan $\mathrm{KCl}$, label, fungisida, insektisida, air, dan bahan-bahan lain yang mendukung penelitian ini. Alat yang digunakan yaitu cangkul untuk membersihkan gulma pada rumah plastik, pisau/cutter untuk memotong-motong plastik, label sebagai penanda, meteran untuk mengukur, DHL meter untuk mengukur daya hantar listrik media tanam, sprayer untuk mengaplikasikan antioksidan, timbangan analitik untuk menimbang pupuk, antioksidan, dan bobot, gembor untuk menyiram, parang untuk memotong bambu, tang untuk mengikat kawat, tangga untuk membangun rumah plastik, selang pada media tanam untuk memudahkan penyiraman, jangka sorong digital untuk mengukur diameter batang, dan alat tulis untuk mencatat data.

Penelitian ini menggunakan Rancangan Acak Kelompok (RAK) dengan 2 faktor yaitu: Faktor I: genotipe Grobogan $\times$ Anjasmoro (G1) $(\mathrm{F} 5)$ dan genotipe Grobogan $\times$ Grobogan (G2) (F5). Faktor II: konsentrasi alfatokoferol dengan taraf yaitu $0 \mathrm{ppm}\left(\mathrm{A}_{0}\right), 250 \mathrm{ppm}\left(\mathrm{A}_{1}\right), 500$ $\operatorname{ppm}\left(\mathrm{A}_{2}\right)$, dan $750 \mathrm{ppm}\left(\mathrm{A}_{3}\right)$.

Data hasil penelitian dianalisis dengan menggunakan sidik ragam berdasarkan model linier sebagai berikut: Yijk $=\mu+\rho i+\alpha j+\beta k+(\alpha \beta) j k+\varepsilon i j k$ Jika hasil sidik ragam menunjukkan pengaruh yang nyata, maka analisis dilanjutkan dengan menggunakan Uji Jarak Berganda Duncan pada taraf $\alpha=5 \%$.
Parameter yang di amati adalah ; tinggi tanaman $(\mathrm{cm})$ diukur dengan menggunakan meteran, diukur dari pangkal sampai titik tumbuh, mulai 2 MST sampai tanaman mulai berbunga, karena varietas kedelai yang digunakan termasuk tanaman determinate. diberikan stik sebagai penanda pengambilan data parameter tinggi tanaman

Peubah amatan jumlah daun dengan cara menghitung jumlah daun, mulai 2 MST sampai tanaman mulai berbunga, karena varietas kedelai yang di gunakan termasuk tanaman determinate. Jumlah cabang produktif (cabang) adalah jumlah cabang yang memiliki polong pada setiap tanaman dihitung dengan menghitung jumlah cabang tersebut pada saat memasuki masa panen. Diameter batang $(\mathrm{mm})$ diambil sekitar $1 \mathrm{~cm}$ di atas permukaan tanah dengan menggunakan jangka sorong pada saat memasuki masa panen. Umur berbunga (hari) diambil pengamatannya pada saat tanaman mulai berbunga sebanyak $80 \%$ per plot. Dan pada Umur panen diambil pada saat tanaman telah memasuki vase $\mathrm{R} 8$, yaitu tanaman telah mengering dan tanaman telah berubah menjadi kecoklatan.

Jumlah polong berisi (polong) dihitung dengan cara menghitung semua polong yang terbentuk dan berisi biji pada setiap tanaman. Pengamatan dilakukan pada saat panen. Bobot kering biji per tanaman (g) dihitung dengan menimbang bobot biji per tanaman dengan timbangan analitik. Biji yang ditimbang adalah biji yang telah dijemur di bawah sinar matahari sampai kadar air 12\% (Jumirawati 2008). Pengamatan bobot 100 biji dilakukan pada saat panen.Bobot 100 butir biji di ambil dari setiap ulangan kemudian bobot 100 biji tersebut di timbang dengan menggunakan timbangan analitik. 


\section{HASIL DAN PEMBAHASAN}

\section{Tinggi Tanaman}

Data pengamatan tinggi tanaman diketahui bahwa genotip kedelai berpengaruh nyata terhadap tinggi tanaman pada 2, 3 dan 5 MST, sedangkan pada perlakuan pemberian alfatokoferol berpengaruh nyata pada umur pengamatan 6, 7 dan 8 MST dan interaksi kedua perlakuan tidak berpengaruh nyata terhadap tinggi tanaman. Rataan tinggi tanaman dua genotip dan pemberian alfatokoferol pada umur 2-8 MST dapat dilihat pada Tabel 1.

Berdasarkan Tabel 1 tampak bahwa pada data pengamatan 2,3 dan 5 MST perlakuan Glberbeda nyata dengan perlakuan G2. Hal ini dapat dilihat pada 2 dan 3 MST pertumbuhan tinggi tanaman pada G1 lebih tinggi dibandingkan dengan
G2 namun pada 5 MST pertumbuhan G2 lebih tinggi dibandingkan dengan G1.

Pada peubah amatan tinggi tanaman dari 4,6,7 dan 8 , jumlah daun dari 2-6, dan produksi per tanaman tidak memperlihatkan perbedaan yang nyata. Menurut Hartmann, et.al (2001) bahwa faktor genetik tanaman dan adaptasi terhadap lingkungan tidak sama sehingga menghasikan pertumbuhan yang berbeda. Setiap terjadinya perubahan kondisi lingkungan di sekitar tanaman akan menyebabkan respons genetik yang berbeda untuk setiap tanaman. Akan tetapi keadaan ini tergantung pada derajat perubahan fisik lingkungan, terutama pada periode-periode pertumbuhan kritis tanaman. Dalam hal ini diduga bahwa setiap genotipe memiliki respon yang hampir sama terhadap kondisi lingkungan sehingga tidak menunjukan perbedaan.

Tabel 1. Rataan tinggi tanaman (cm) pada dua genotipe dan konsentrasi alfatokoferol

\begin{tabular}{|c|c|c|c|c|c|c|}
\hline \multirow[t]{2}{*}{ MST } & \multirow[b]{2}{*}{ Genotipe } & \multicolumn{4}{|c|}{ alfatokoferol } & \multirow[b]{2}{*}{ Rataan } \\
\hline & & $\begin{array}{c}\mathrm{A} 0 \\
\text { (kontrol) }\end{array}$ & $\begin{array}{c}\mathrm{A} 1 \\
(250 \mathrm{ppm})\end{array}$ & A2 (500ppm) & $\begin{array}{c}\mathrm{A} 3 \\
\text { (750ppm) }\end{array}$ & \\
\hline \multirow{2}{*}{$2 \mathrm{MST}$} & G1 (Anjasmoro $\times$ Grobogan $)$ & 12,29 & 14,06 & 12,19 & 11,81 & $12,59 \mathrm{a}$ \\
\hline & G2 $($ Grobogan $\times$ Grobogan $)$ & 9,65 & 9,17 & 10,02 & 10,55 & $9,85 \mathrm{~b}$ \\
\hline & Rataan & 10,97 & 11,61 & 11,10 & 11,18 & \\
\hline \multirow{3}{*}{$3 \mathrm{MST}$} & G1 $($ Anjasmoro $\times$ Grobogan $)$ & 14,63 & 18,15 & 16,15 & 16,01 & $16,24 \mathrm{a}$ \\
\hline & G2 (Grobogan $\times$ Grobogan) & 14,05 & 14,00 & 13,81 & 14,92 & $14,20 \mathrm{~b}$ \\
\hline & Rataan & 14,34 & 16,08 & 14,98 & 15,46 & \\
\hline \multirow{3}{*}{$4 \mathrm{MST}$} & G1 (Anjasmoro $\times$ Grobogan $)$ & 20,83 & 26,35 & 23,91 & 24,52 & 23,90 \\
\hline & G2 $($ Grobogan $\times$ Grobogan $)$ & 24,07 & 22,57 & 24,89 & 23,95 & 23,87 \\
\hline & Rataan & 22,45 & 24,46 & 24,40 & 24,24 & \\
\hline \multirow{3}{*}{$5 \mathrm{MST}$} & G1(Anjasmoro $\times$ Grobogan $)$ & 29,09 & 37,22 & 32,95 & 34,30 & $33,39 \mathrm{~b}$ \\
\hline & G2 $($ Grobogan $\times$ Grobogan $)$ & 37,20 & 36,32 & 38,57 & 37,16 & $37,31 \mathrm{a}$ \\
\hline & Rataan & 33,14 & 36,77 & 35,76 & 35,73 & \\
\hline \multirow{3}{*}{$6 \mathrm{MST}$} & G1 $($ Anjasmoro $\times$ Grobogan $)$ & 36,57 & 50,35 & 45,99 & 48,10 & 45,25 \\
\hline & G2 (Grobogan $\times$ Grobogan) & 42,29 & 48,52 & 49,84 & 47,56 & 47,05 \\
\hline & Rataan & $39,43 \mathrm{~b}$ & $49,43 \mathrm{a}$ & $47,92 \mathrm{a}$ & $47,83 \mathrm{a}$ & \\
\hline \multirow{3}{*}{$7 \mathrm{MST}$} & G1 (Anjasmoro $\times$ Grobogan $)$ & 39,87 & 53,55 & 51,79 & 51,27 & 49,12 \\
\hline & G2 $($ Grobogan $\times$ Grobogan $)$ & 43,99 & 50,83 & 52,49 & 50,90 & 49,55 \\
\hline & Rataan & $41,93 \mathrm{~b}$ & $52,19 \mathrm{a}$ & $52,14 \mathrm{a}$ & $51,09 \mathrm{a}$ & \\
\hline \multirow{3}{*}{$8 \mathrm{MST}$} & G1 $($ Anjasmoro $\times$ Grobogan $)$ & 43,21 & 57,06 & 56,94 & 55,47 & 53,17 \\
\hline & G2 (Grobogan $\times$ Grobogan $)$ & 46,64 & 52,03 & 55,14 & 53,47 & 51,82 \\
\hline & Rataan & $44,92 \mathrm{~b}$ & $54,54 \mathrm{a}$ & $56,04 \mathrm{a}$ & $54,47 \mathrm{a}$ & \\
\hline
\end{tabular}

Keterangan: Angka yang diikuti notasi yang sama pada baris atau kolompok kolom yang sama menunjukan berbeda tidak nyata menurut Uji Jarak Berganda Duncan pada taraf 5\% 


\section{Jumlah Daun}

Tabel 2. Rataan jumlah daun (helai)2-8 MST pada perlakuan genotipe dan konsentrasi alfatokoferol

\begin{tabular}{|c|c|c|c|c|c|c|}
\hline \multicolumn{2}{|r|}{ Genotipe } & \multicolumn{4}{|c|}{ Alfatokoferol } & \multirow[b]{2}{*}{ Rataan } \\
\hline \multirow{3}{*}{$2 \mathrm{MST}$} & & $\begin{array}{c}\mathrm{A} 0 \\
\text { (kontrol) }\end{array}$ & $\begin{array}{c}\mathrm{A} 1 \\
(250 \mathrm{ppm})\end{array}$ & $\begin{array}{c}\mathrm{A} 2 \\
(500 \mathrm{ppm})\end{array}$ & $\begin{array}{c}\mathrm{A} 3 \\
(750 \mathrm{ppm})\end{array}$ & \\
\hline & G1(Anjasmoro $\times$ Grobogan) & 2,93 & 3,40 & 3,00 & 2,93 & 3,07 \\
\hline & G2 $($ Grobogan $\times$ Grobogan $)$ & 2,93 & 2,53 & 2,73 & 2,93 & 2,78 \\
\hline & Rataan & 2,93 & 2,97 & 2,87 & 2,93 & \\
\hline \multirow{2}{*}{$3 \mathrm{MST}$} & G1(Anjasmoro $\times$ Grobogan) & 3,73 & 4,20 & 4,00 & 4,07 & 4,00 \\
\hline & G2 (Grobogan × Grobogan $)$ & 4,00 & 3,73 & 3,87 & 4,13 & 3,93 \\
\hline & Rataan & 3,87 & 3,97 & 3,93 & 4,10 & \\
\hline \multirow{2}{*}{$4 \mathrm{MST}$} & G1(Anjasmoro $\times$ Grobogan) & $4,60 \mathrm{~b}$ & $5,60 \mathrm{a}$ & $5,53 \mathrm{ab}$ & $5,87 \mathrm{a}$ & 5,40 \\
\hline & G2 (Grobogan $\times$ Grobogan $)$ & $5,60 \mathrm{a}$ & $4,80 \mathrm{~b}$ & $6,07 \mathrm{a}$ & $5,73 \mathrm{a}$ & 5,55 \\
\hline & Rataan & $5,10 \mathrm{~b}$ & $5,20 \mathrm{~b}$ & $5,80 \mathrm{a}$ & $5,80 \mathrm{a}$ & \\
\hline \multirow{2}{*}{$5 \mathrm{MST}$} & G1(Anjasmoro $\times$ Grobogan) & $5,67 \mathrm{c}$ & $7,47 \mathrm{ab}$ & $7,27 \mathrm{ab}$ & $7,73 \mathrm{ab}$ & 7,03 \\
\hline & G2 $($ Grobogan $\times$ Grobogan $)$ & $7,93 \mathrm{ab}$ & $7,13 \mathrm{bc}$ & $8,53 \mathrm{a}$ & $7,73 \mathrm{ab}$ & 7,83 \\
\hline & Rataan & 6,80 & 7,30 & 7,90 & 7,73 & \\
\hline \multirow{2}{*}{$6 \mathrm{MST}$} & G1(Anjasmoro $\times$ Grobogan) & 8,33 & 10,67 & 10,80 & 10,27 & 10,02 \\
\hline & G2 (Grobogan × Grobogan $)$ & 10,73 & 10,07 & 12,27 & 10,53 & 10,90 \\
\hline & Rataan & 9,53 & 10,37 & 11,53 & 10,40 & \\
\hline \multirow{2}{*}{$7 \mathrm{MST}$} & G1(Anjasmoro $\times$ Grobogan) & 11,47 & 14,20 & 14,00 & 14,00 & $13,42 \mathrm{a}$ \\
\hline & G2 (Grobogan × Grobogan $)$ & 11,53 & 11,27 & 13,47 & 11,47 & $11,93 \mathrm{~b}$ \\
\hline & Rataan & 11,50 & 12,73 & 13,73 & 12,73 & \\
\hline \multirow{3}{*}{$8 \mathrm{MST}$} & G1(Anjasmoro $\times$ Grobogan) & 15,07 & 17,67 & 18,47 & 16,93 & $17,03 \mathrm{a}$ \\
\hline & G2 (Grobogan× Grobogan) & 12,47 & 12,53 & 14,93 & 12,60 & $13,13 \mathrm{~b}$ \\
\hline & Rataan & $13,77 \mathrm{~b}$ & $15,10 \mathrm{ab}$ & $16,70 \mathrm{a}$ & $14,77 \mathrm{ab}$ & \\
\hline
\end{tabular}

Keterangan: Angka yang diikuti notasi yang sama pada baris atau kolompok kolom yang sama menunjukan berbeda tidak nyata menurut Uji Jarak Berganda Duncan pada taraf 5\%

Berdasarkan data pengamatan jumlah daun di ketahui bahwa genotipe kedelai berpengaruh nyata terhadap jumlah daun pada 5,7 dan $8 \mathrm{MST}$, pemberian konsentrasi alfatokoferol berpengaruh nyata pada 4 dan 8 MST, dan interaksi genotipe dengan alfatokoferol berpengaruh nyata terhadap jumlah daun pada 4 dan 5 MST.

Berdasarkan Tabel 2 tampak bahwa pada data pengamatan 5, 7 dan 8 MST perlakuan G1 berbeda nyata dengan perlakuan. Hal ini dapat dilihat pada 5, 7 dan 8 MST pertambahan jumlah daun padaG1 lebih tinggi dibandingkan dengan G2. Pada 8 MST perlakuan G1 menghasilkan jumlah daun tertinggi $(17,03)$ yang berbeda nyata dengan perlakuan (Genotipe Grobogan $\times$ Grobogan).
Hasil analisis jumlah daun (Tabel 2), pada 4 dan 5 MST menunjukkan (G2A2) Genotipe Grobogan × Grobogan dengan aplikasi Alfatokoferol 500 ppm menghasilkan rataan tertinggi yakni 6,07 helai (4 MST), 8,53 helai (5 MST) dan rataan terendah pada perlakuan G1A0 yaitu Genotipe Anjasmoro $\times$ Grobogantanpa Alfatokoferol) yakni 4,60 helai (4 MST) 5,67 helai (5 MST). Hal ini diduga genotipe G1 sangat sensitif terhadap cekaman salinitas pada 6-7 dS/m, namun dengan pemberian alfatokoferol diyakini dapat membantu tanaman melindungi memberan kloroplas dari fotooksidasi dan dapat pula membantu untuk menyediakan kondisi yang optimal untuk proses fotosintesis 


\section{Diameter batang (mm)}

Tabel 3. Rataan diameter batang $(\mathrm{mm})$ pada perlakuan genotipe dan konsentrasi alfatokoferol

\begin{tabular}{lccccc}
\hline \multirow{2}{*}{ Perlakuan } & \multicolumn{5}{c}{ Alfatokoferol } \\
\cline { 2 - 6 } & $\begin{array}{c}\text { A0 } \\
(\text { kontrol })\end{array}$ & $\begin{array}{c}\text { A1 } \\
(250 \mathrm{ppm})\end{array}$ & $\begin{array}{c}\text { A2 } \\
(500 \mathrm{ppm})\end{array}$ & $\begin{array}{c}\text { A3 } \\
(750 \mathrm{ppm})\end{array}$ & Rataan \\
\hline G1 (Anjasmoro $\times$ Grobogan) & 4,02 & 4,34 & 4,18 & 4,26 & $4,20 \mathrm{a}$ \\
G2 (Grobogan $\times$ Grobogan) & 3,70 & 3,68 & 4,18 & 3,80 & $3,84 \mathrm{~b}$ \\
\hline Rataan & 3,86 & 4,01 & 4,18 & 4,03 & \\
\hline
\end{tabular}

Keterangan: Angka yang diikuti notasi yang sama pada kolom yang sama menunjukan berbeda tidak nyata menurut Uji Jarak Berganda Duncan pada taraf 5\%

Berdasarkan Tabel 3 tampak bahwa pada data pengamatan diameter batang tanaman perlakuan G1 berbeda nyata dengan perlakuan G2. perlakuan G1 menghasilkan diameter batang tertinggi $(4,20)$ yang berbeda nyata dengan perlakuan G2 yang menghasilkan diameter batang $(3,84)$.

Diameter batang terbesar terdapat pada genotipe Anjasmoro $\times$ Grobogan (G1) dengan jumlah 4,20 mm. Adanya perbedaan yang beragam pada masingmasing genotipe diduga disebabkan adanya perbedaan genetik pada kedua genotipe kedelai yang ditanam. Perbedaan genetik ini mengakibatkan setiap genotipe memiliki ciri dan sifat khas yang berbeda satu sama lain sehingga akan menunjukan keragaman penampilan. Seperti yang dikemukakan oleh Sitompul dan Guritno (1995) bahwa perbedaan susunan genetik merupakan salah satu faktor penyebab keragaman penampilan tanaman. Hasil penelitian menujukan pertumbuhan dan produksi genotipe (G1) lebih baik dibandingkan (G2).

\section{Cabang produktif}

Berdasarkan Tabel 4 tampak bahwa pada data pengamatan cabang produktif perlakuan G1 berbeda nyata dengan perlakuan G2. perlakuan G1 menghasilkan cabang produktif tertinggi $(5,02)$ yang berbeda nyata dengan perlakuan G2 yang menghasilkan cabang produktif $(2,56)$.

Adanya perbedaan yang beragam pada masing-masing genotipe diduga disebabkan adanya perbedaan genetik pada kedua genotipe kedelai yang ditanam. Perbedaan genetik ini mengakibatkan setiap genotipe memiliki ciri dan sifat khas yang berbeda satu sama lain sehingga akan menunjukan keragaman penampilan. Seperti yang dikemukakan oleh Sitompul dan Guritno (1995) bahwa perbedaan susunan genetik merupakan salah satu faktor penyebab keragaman penampilan tanaman.Hasil penelitian menujukan pertumbuhan dan produksi genotype Anjasmoro $\times$ Grobogan (G1) lebih baik dibandingkan Genotipe Grobogan $\times$ Grobogan (G2).

Tabel 4. Rataan cabang produktif pada perlakuan genotipe dan konsentrasi alfatokoferol

\begin{tabular}{cccccc}
\hline \multirow{2}{*}{ Perlakuan } & \multicolumn{5}{c}{ Alfatokoferol } \\
\cline { 2 - 6 } & $\begin{array}{c}\mathrm{A} 0 \\
(\text { kontrol })\end{array}$ & $\begin{array}{c}\mathrm{A} 1 \\
(250 \mathrm{ppm})\end{array}$ & $\begin{array}{c}\mathrm{A} 2 \\
(500 \mathrm{ppm})\end{array}$ & $\begin{array}{c}\mathrm{A} 3 \\
(750 \mathrm{ppm})\end{array}$ & Rataan \\
\hline G1(Anjasmoro $\times$ Grobogar & 5,42 & 5,58 & 4,83 & 4,25 & $5,02 \mathrm{a}$ \\
G2(Grobogan $\times$ Grobogan) & 2,17 & 2,92 & 3,00 & 2,17 & $2,56 \mathrm{~b}$ \\
\hline Rataan & 3,79 & 4,25 & 3,92 & 3,21 & \\
\hline
\end{tabular}

Keterangan: Angka yang diikuti notasi yang sama pada kolom yang sama menunjukan berbeda tidak nyata menurut Uji Jarak Berganda Duncan pada taraf 5\% 


\section{Umur berbunga}

Tabel 5. Rataan umur berbunga (HST) pada perlakuan genotipe dan konsentrasi alfatokoferol

\begin{tabular}{lccccc}
\hline \multirow{2}{*}{ Perlakuan } & \multicolumn{5}{c}{ Alfatokoferol } \\
\cline { 2 - 6 } & $\begin{array}{c}\mathrm{A} 0 \\
(\text { kontrol })\end{array}$ & $\begin{array}{c}\mathrm{A} 1 \\
(250 \mathrm{ppm})\end{array}$ & $\begin{array}{c}\mathrm{A} 2 \\
(500 \mathrm{ppm})\end{array}$ & $\begin{array}{c}\mathrm{A} 3 \\
(750 \mathrm{ppm})\end{array}$ & Rataan \\
\hline G1(Anjasmoro $\times$ Grobogan) & 37,00 & 36,67 & 37,67 & 36,67 & $37,00 \mathrm{a}$ \\
G2(Grobogan $\times$ Grobogan) & 32,67 & 33,67 & 34,33 & 33,67 & $33,58 \mathrm{~b}$ \\
\hline Rataan & 34,83 & 35,17 & 36,00 & 35,17 & \\
\hline
\end{tabular}

Keterangan: Angka yang diikuti notasi yang sama pada kolom yang sama menunjukan berbeda tidak nyata menurut Uji Jarak Berganda Duncan pada taraf 5\%

Berdasarkan Tabel 5 tampak bahwa pada data pengamatan umur berbunga perlakuan G1 berbeda nyata dengan perlakuan G2.Hal ini dapat dilihat pada G1 lebih tinggi dibandingkan dengan G2.perlakuan G1 menghasilkan umur berbunga paling lama $(37,00)$ yang berbeda nyata dengan perlakuan G2 yang menghasilkan umur berbunga paling cepat $(33,58)$

Hal ini sesuai dengan hasil penelitian Sadak dan Mona (2014) yang menyatakan bahwa alfatokoferol (vitamin E) adalah antioksidan lipofilik disintesis oleh semua tanaman; tingkat yang berbeda-beda dalam jaringan yang berbeda dan berfluktuasi selama pengembangan dan dalam menanggapi cekaman abiotik.

\section{Umur panen (HST)}

Berdasarkan Tabel 6 tampak bahwa pada data pengamatan umur berbunga perlakuan G1 berbeda nyata dengan perlakuan G2.Hal ini dapat dilihat pada G1 lebih lama dibandingkan dengan G2.perlakuan G1 menghasilkan umur panen paling lama $(93,69$ hari $)$ yang berbeda nyata dengan perlakuan G2 yang menghasilkan umur panen paling cepat (92,25 hari).

Umur panen tercepat terdapat pada Grobogan $\times$ Grobogan (G2) dengan umur panen 92,25 hari. Bobot 100 biji terbesar terdapat pada Grobogan $\times$ Grobogan (G2) dengan berat 20,73 g. Adanya perbedaan yang beragam pada masing-masing genotipe diduga disebabkan adanya perbedaan genetik pada kedua genotipe kedelai yang ditanam. Perbedaan genetik ini mengakibatkan setiap genotipe memiliki ciri dan sifat khas yang berbeda satu sama lain sehingga akan menunjukan keragaman penampilan. Seperti yang dikemukakan oleh Sitompul dan Guritno (1995) bahwa perbedaan susunan genetik merupakan salah satu faktor penyebab keragaman penampilan tanaman. Hasil penelitian menujukan pertumbuhan dan produksi genotipe Anjasmoro $\times$ Grobogan (G1) lebih baik dibandingkan Genotipe Grobogan $\times$ Grobogan (G2)

Tabel 6. Rataan umur panen (HST) pada perlakuan genotipe dan konsentrasi alfatokoferol

\begin{tabular}{lccccc}
\hline \multirow{2}{*}{ Perlakuan } & \multicolumn{5}{c}{ Alfatokoferol } \\
\cline { 2 - 6 } & $\begin{array}{c}\mathrm{A} 0 \\
(\text { kontrol })\end{array}$ & $\begin{array}{c}\mathrm{A} 1 \\
(250 \mathrm{ppm})\end{array}$ & $\begin{array}{c}\mathrm{A} 2 \\
(500 \mathrm{ppm})\end{array}$ & $\begin{array}{c}\mathrm{A} 3 \\
(750 \mathrm{ppm})\end{array}$ & Rataan \\
\hline G1(Anjasmoro $\times$ Grobogan) & 92,58 & 93,50 & 94,75 & 93,92 & $93,69 \mathrm{a}$ \\
G2(Grobogan $\times$ Grobogan) & 90,42 & 93,25 & 92,50 & 92,83 & $92,25 \mathrm{~b}$ \\
\hline Rataan & 91,50 & 93,38 & 93,63 & 93,38 & \\
\hline
\end{tabular}

Keterangan: Angka yang diikuti notasi yang sama pada kolom yang sama menunjukan berbeda tidak nyata menurut Uji Jarak Berganda Duncan pada taraf 5\% 


\section{Jumlah polong berisi}

Tabel 7. Rataan jumlah polong berisi dan jumlah polong hampa per tanaman pada perlakuan genotipe dan konsentrasi alfatokoferol

\begin{tabular}{cccccc}
\hline \multirow{2}{*}{ Perlakuan } & \multicolumn{5}{c}{ Alfatokoferol } \\
\cline { 2 - 6 } & $\begin{array}{c}\mathrm{A} 0 \\
(\text { kontrol) }\end{array}$ & $\begin{array}{c}\mathrm{A} 1 \\
(250 \mathrm{ppm})\end{array}$ & $\begin{array}{c}\mathrm{A} 2 \\
(500 \mathrm{ppm})\end{array}$ & $\begin{array}{c}\mathrm{A} 3 \\
(750 \mathrm{ppm})\end{array}$ & Rataan \\
\hline G1(Anjasmoro $\times$ Grobogan) & 24,17 & 29,08 & 29,50 & 29,83 & $28,15 \mathrm{a}$ \\
G2(Grobogan $\times$ Grobogan) & 19,33 & 15,33 & 21,33 & 17,83 & $18,46 \mathrm{~b}$ \\
\hline Rataan & 21,75 & 22,21 & 25,42 & 23,83 & \\
\hline
\end{tabular}

Keterangan: Angka yang diikuti notasi yang sama pada kolom yang sama menunjukan berbeda tidak nyata menurut Uji Jarak Berganda Duncan pada taraf 5\%

Berdasarkan Tabel 7 tampak bahwa pada data pengamatan jumlah polong berisi perlakuanG1 berbeda nyata dengan perlakuan G2.Hal ini dapat dilihat pada G1 lebih banyak dibandingkan dengan G2.perlakuan G1 menghasilkan jumlah polong berisi paling banyak $(28,15)$ yang berbeda nyata dengan perlakuan yang menghasilkan jumlah polong paling sedikit $(18,46)$

Jumlah polong berisi terbanyak terdapat pada Anjasmoro $\times$ Grobogan $(\mathrm{G} 1)$ dengan jumlah28,15 buah. Adanya perbedaan yang beragam pada masingmasing genotipe diduga disebabkan adanya perbedaan genetik pada kedua genotipe kedelai yang ditanam. Perbedaan genetik ini mengakibatkan setiap genotipe memiliki ciri dan sifat khas yang berbeda satu sama lain sehingga akan menunjukan keragaman penampilan. Seperti yang dikemukakan oleh Sitompul dan Guritno (1995) bahwa perbedaan susunan genetik merupakan salah satu faktor penyebab keragaman penampilan tanaman. Hasil penelitian menujukan pertumbuhan dan produksi genotipe Anjasmoro $\times$ Grobogan (G1) lebih baik dibandingkan Genotipe Grobogan $\times$ Grobogan (G2).

\section{Bobot 100 biji ulangan tanaman (g)}

Berdasarkan Tabel 8 tampak bahwa pada data pengamatan produksi biji per tanaman perlakuan G1 tidak berbeda nyata dengan perlakuan G2.Hal ini dapat dilihat pada G1 lebih tinggi dibandingkan dengan
G2.perlakuan G1 menghasilkan produksi biji per tanaman tertinggi $(7,66)$ yang berbeda nyata dengan perlakuan G2 yang menghasilkan produksi biji pertanaman terrendah $(7,44)$.

Hasil analisis jumlah polong berisi, bobot 100 biji perulangan, dan produksi biji pertanaman menunjukan bahwa perlakuan A2 (alfatokoferol 500 ppm) menghasilkan hasil rataan tertinggi dibandingkan dengan perlakuan lainnya.Hal ini sesuai dengan pernyataan Hussein et al (2007) yang menyatakan bahwa pada tanaman, alfatokoferoldiyakini berfungsi untuk melindungi membran kloroplas dari foto-oksidasi dan membantu untuk menyediakan kondisi yang optimal untuk proses fotosintesis. Fungsi alfatokoferol terkait dengan fungsinya sebagai antioksidan yang paling menonjol di antaranya adalah perlindungan asam lemak tak jenuh ganda dari lipid peroksidasi dengan pendinginan dan pembilasan berbagai radikal oksigen reaktif (ROS) termasuk oksigen singlet, radikal superoksida dan radikal alkil peroksi, alfatokoferol melindungi memberan kloroplas dari foto-oksidasi dan membantu mengoptimalkan dalam peroses fotosintesis . Pada tanaman, konsentrasi tokoferol bervariasi dalam jaringan yang berbeda dan berfluktuasi selama fase perkembangan dan pada tanggap terhadap cekaman abiotik. 
Tabel 8. Rataan jumlah bobot 100 biji(g) per ulangan pada perlakuan genotipe dan konsentrasi alfatokoferol

\begin{tabular}{cccccc}
\hline \multirow{2}{*}{ Perlakuan } & \multicolumn{5}{c}{ Alfatokoferol } \\
\cline { 2 - 6 } & $\begin{array}{c}\mathrm{A} 0 \\
(\text { kontrol })\end{array}$ & $\begin{array}{c}\mathrm{A} 1 \\
(250 \mathrm{ppm})\end{array}$ & $\begin{array}{c}\mathrm{A} 2 \\
(500 \mathrm{ppm})\end{array}$ & $\begin{array}{c}\mathrm{A} 3 \\
(750 \mathrm{ppm})\end{array}$ & Rataan \\
\hline G1(Anjasmoro $\times$ Grobogan) & 12,73 & 13,47 & 15,25 & 12,38 & $13,46 \mathrm{a}$ \\
G2(Grobogan $\times$ Grobogan) & 16,25 & 17,41 & 16,40 & 16,19 & $16,59 \mathrm{~b}$ \\
\hline Rataan & 14,49 & 15,44 & 15,83 & 14,29 & \\
\hline
\end{tabular}

Keterangan: Angka yang diikuti notasi yang sama pada kolom yang sama menunjukan berbeda tidak nyata menurut Uji Jarak Berganda Duncan pada taraf 5\%

\section{SIMPULAN}

Kedua genotipe kedelai berpengaruh nyata pada parameter tinggi tanaman, jumlah daun, diameter batang, cabang produktif,umur berbunga, umur panen, jumlah polong berisi dan bobot 100 biji, genotipe Anjasmoro $\times$ Grobogan menunjukan pertumbuhan dan produksi yang lebih baik dibandingkan genotipe Grobogan $\times$ Grobogan. Pemberian alfatokoferol berpengaruh nyata terhadap tinggi tanaman dan jumlah daun dengan konsentrasi 500 ppm (A2) tetapi tidak berpengaruh nyata pada parameter lainnya.Aplikasi alfatokoferol pada dua genotipe kedelai berpengaruh nyata pada jumlah daun 4 dan 5 Mst tetapi berpengaruh tidak nyata terhadap parameter lainnya.

\section{DAFTAR PUSTAKA}

Ardiansyah, M. 2013. Respons Pertumbuhan dan Produksi Kedelai Hasil Seleksi Terhadap Pemberian Asam Askorbat dan Inokulasi Fungi Mikoriza Arbuskular di Tanah Salin. Universitas Sumatera Utara. Medan.

BPS. 2014. Badan Pusat Statitsitik. Luas panen, produksi dan produktivitas kedelai. http://www.bps.go.id. Diakses tanggal 20 Februari 2017

Farouk, S. 2011. Ascorbic acid and $\alpha$ tocopherol minimize salt-induced wheat leaf senescence. Journal of
Stress Physiology \&

Biochemistry. Vol.7 No.

Hartmann. D.L, leslie. A. M, and Qiang $\mathrm{Fu}, 2001$. Tropical Convection and the Energy Balance at the Top of the Atmosphere, Department of Atmospheric Sciences, University of Washington, Seattle, Washington.

Hussein, M.M., Balbaa, L.K. dan Gaballah, M.S. 2007. Developing a Salt Tolerant Cowpea Using Alpha Tocopherol. J. Appl. Sci. Res., 3(10): 1234-1239

Jumrawati. 2008. Efektivitas Inokulasi Rhizobium sp. terhadap Pertumbuhan dan Hasil Kedelai pada Tanah Jenuh Air. Dinas Pertanian Provinsi Sulawesi Tenggara.

Ramadhani, E. 2009. Respons Pertumbuhan dan Produksi Kedelai (Glycine max (L.) Merril.) terhadap Perbedaan Waktu Tanam dan Inokulasi Rhizobium. Universitas Sumatera Utara. Medan.

Sadak, M. S. dan Mona, G. W. 2014. Role of ascorbic acid and alpha tocopherol in alleviating salinity stress on flax plant (Linum usitatissimum L.). Journal of Stress Physiology and Biochemistry, Vol. 10 No. 1.

Sitompul, S.M dan B. Gurito, 1995. Analisis Pertumbuhan Tanaman Gadjahmada University Press, Yogyakarta 
Triyani, A., Suwarto Dan Siti Nurchasana, 2013. Toleran Genotip Kedelai (glycine $\max (\mathrm{L})$. Merril ) Terhadap Konsentrasi Garam
NACL pada Fase Vegetatif, Fakultas Pertanian, Universitas Jendral Sudirman, Purwokerto. 